\title{
Farmer beliefs about climate change and carbon sequestration incentives
}

\author{
Benjamin M. Gramig ${ }^{1, *}$, Jessa M. Barnard ${ }^{1}$, Linda S. Prokopy ${ }^{2}$ \\ ${ }^{1}$ Department of Agricultural Economics and ${ }^{2}$ Department of Forestry and Natural Resources, Purdue University, \\ 403 W. State Street, West Lafayette, Indiana 47907, USA
}

\begin{abstract}
Agricultural land management practices are frequently discussed in the context of domestic and international policies to mitigate and adapt to future climate change. Agriculture has not been one of the economic sectors covered by proposed or enacted greenhouse gas emissions limits; thus, agriculture has been the subject of much research on its technical and economic potential to mitigate climate change impacts. We report the results of a survey of Indiana row crop farmers' $(\mathrm{n}=724)$ beliefs about climate change, the effect of climate change on their farm operation, and the best way to create incentives for farmers to store more carbon in agricultural soils. Farmer beliefs and their strength of opinions about these issues are important for developing future policy proposals, decision support tools, and emissions markets that involve agricultural emissions offsets. We found that $79 \%$ of surveyed Indiana farmers believe that climate change is an ongoing natural process, compared to $45 \%$ who believe that human activities are contributing to climate change. A total of $31 \%$ of respondents expressed neither belief nor disbelief that humans are contributing to climate change, suggesting that nearly one-third of respondents either do not know or have not made up their minds about the causes of climate change. We found clear differences in farmers' beliefs about occurrence and causes of climate change compared to the general population. Our results suggest that farmers require a better understanding of the expected effects of climate change on weather and cropping systems management, and that farmers' beliefs are capable of being informed through outreach and extension of climate change research.
\end{abstract}

KEY WORDS: Climate change beliefs · Farmers · Outreach · Survey · Carbon sequestration

\section{INTRODUCTION}

Agricultural land management practices are frequently discussed in the context of domestic and international policies to mitigate and adapt to future climate change (Smith et al. 2007). Agricultural lands have the ability to sequester atmospheric carbon and, through the use of appropriate cropping and fertilization practices, can reduce fluxes of other more potent greenhouse gas (GHG) emissions from the soil. Agricultural, economic and climate researchers have been working to inform policy makers, agri- cultural producers, industry and the general public about options for the design of different mechanisms to control emissions (Paustian et al. 2004). However, despite the agricultural sector's contribution to anthropogenic greenhouse gas (GHG) emissions (USEPA 2012), it has not yet been covered by proposed or enacted greenhouse gas emissions limits in the United States (US) .

The adaptation of cropping systems management to cope with climate change is important for several reasons, including increasing temperatures, changes in precipitation and pest/disease patterns, and in- 
creasing occurrence of extreme events (Malcolm et al. 2012, Rosenzweig et al. 2001). A great deal of modeling work has been conducted to understand the impacts of climate change on agriculture (e.g. Easterling et al. 1993, Mearns et al. 2001), but there has been little equivalent study on how farmers are likely to adapt to these changes (for one example, see Howden et al. 2003). Agricultural adaptation is influenced by a variety of factors (e.g. climatic, societal and existing farm management), takes place at different geographical scales, and covers both shortand long-term adjustments (Chiotti \& Johnston 1995, Olesen \& Bindi 2002, Smit \& Skinner 2002). The agricultural system already adapts to climatic variability and change in many ad hoc ways including altering planting dates, hybrid selection and irrigation decisions (Easterling 1996). However, at the farm scale, one of the factors required for proactive adaptation to climate change is for farmers to first perceive it as a problem (Brklacich et al. 1997, Maddison 2007, O'Brien et al. 2012).

Although agriculture is one of the largest sectors of the economy and society that can provide relatively low cost climate regulating ecosystem services, very few surveys have captured the opinions and beliefs of farmers in the US regarding production practices or forms of possible economic incentives. Previous surveys and opinion polls in the US have attempted to gather the general public's perception of climate change (e.g. Lorenzoni \& Pidgeon 2006, PRCPP 2010). For example, a study of roughly 1000 American adults found that $75 \%$ believe that the world's temperatures are increasing (Yeager et al. 2011). A similarly designed survey found that $61 \%$ of Americans believe global warming is happening, and that $50 \%$ believe that human activities are contributing to warming (Leiserowitz et al. 2010). It is important to understand farmers' perceptions of climate change because agriculture is an important sub-sector of the global economy that is not only susceptible to climate variability and change, but also has the ability to mitigate future climate change.

To that end, several scholars have suggested that it is important to know how farmers within a specific context are likely to understand climate change (Holloway 1999, Milne 2005). Surprisingly little research on this topic has been conducted around the world, and the majority of the existing research is in Africa. A number of the African studies have found that farmers are generally aware of climate change in that they believe they are experiencing increasing temperatures and decreasing precipitation; however, recent evidence suggests that these percep- tions, especially related to precipitation amounts, are flawed (Maddison 2007, Gbetibouo 2009, Gwimbi 2009, Deressa et al. 2011, Osbahr et al. 2011 Rao et al. 2011). A recent study of Scottish dairy farmer beliefs about climate change investigated the livestock sector (Barnes \& Toma 2012) and found that the surveyed farmers were largely uncertain about the possibility of climate change impacts in the future. In Victoria, Australia, over half of surveyed farmers thought that climate change was a serious problem (Widcorp 2009). Bryant et al. (2000) review several Canadian studies on farmers' perceptions towards climate change from the late 1990s, and found a general sense of skepticism at that time; a survey in southeast England in the same time period found a majority of farmers believed the climate had changed recently (Robinson 1999). In the US, a survey of beef feedlot operators in southwestern Kansas, also in the late 1990s, showed similar results to those in Bryant et al.'s (2000) Canadian study, with farmers having a high level of skepticism about the notion of global warming and minimal concerns that it would impact their operations (Harrington \& Lu 2002). More recent work in the US found that less than half of a surveyed sample of North Carolina farmers believed that climate change has been scientifically proven (Rejesus 2012).

The present study contributes to this field by asking maize and soybean farmers in Indiana about their belief in climate change. We also examine farmers' beliefs about the effect of climate change on their farm operation, and opinions about market-based versus government-supported conservation programs to incentivize adoption of climate change mitigating farm management practices.

The development of useful and usable educational materials and programs, decision-support tools to adapt to climate change, and feasible policy proposals that rely on changes in farmer management to mitigate climate change cannot be expected to be effective if they do not take farmers' baseline knowledge and beliefs about climate change into account. Farmers' beliefs and strength of opinions about these issues are important for developing future public policies or private emissions markets that involve agricultural offsets. Our results offer timely and important insights for the communication of scientific information about adaptation to and mitigation of climate change to the agricultural community. We shed light on which opinions held by farmers may be less entrenched and thus capable of being informed by science through public engagement with the agricultural community. 


\section{DATA AND METHODS}

\subsection{Data collection}

Indiana farmers' climate change perceptions were assessed as part of a state-level conservation tillage adoption survey. Indiana is a midwestern state that produces $7.2 \%$ of all corn and $7.8 \%$ of all soybeans grown in the US (USDA-NASS 2010) and is representative of the Eastern Cornbelt. To construct a sampling frame to represent the population of farmers capable of supplying soil carbon sequestration in Indiana, government farm payment data was obtained from the USDA Farm Service Agency via a Freedom of Information Act Request. This yielded 47107 unique customer identification numbers for farmers who received a payment in 2009 for growing either corn or soybeans. This list frame is comparable in number to the 46373 Indiana corn and soybean farmers identified in the most recent agricultural census (USDA-NASS 2007). It is impossible to precisely determine how closely the population of farmers in the census matches the sampling frame. A simple random sample of 2000 addresses was drawn from the list frame to receive the survey.

The survey instrument consisted of demographic questions (see Table 1 and Table S1 in Supplement 1 at www.int-res.com/articles/suppl/c056p157_ supp.pdf), one question about sources of tillage information, and 10 questions about climate change beliefs and preferred mechanisms to incentivize agricultural soil carbon sequestration (see Table 2). Between planting and harvest during the summer of 2010, farmers were asked basic information about their tillage practices, location of the majority of their farmed land within the state of Indiana, tenure status of farmed land (owned vs. rented), and demographic questions about their age, education level, and how many hours per week they are employed off-farm. Respondents were also asked to respond to 10 statements regarding climate change beliefs, including how climate change is portrayed in the media and how it may affect their farm. These questions were developed based upon responses to open-ended survey questions asked of extension agents and educators in a 12-state region of the Corn Belt as part of a related project addressing cereal crop producers' information and decisionsupport needs related to climate variability and change (U2U 2011). These responses were coded on an ordinal 5-point Likert scale ranging from 1 equals 'Strongly disagree' to 5 equals 'Strongly agree'.
Following the methods in Dillman (2009), a 5-wave survey schedule was followed. Individuals in the sample received a personalized invitation letter with a web address and unique respondent identification number enabling them to respond using the online version of the survey or mail back a completed paper survey. Following the invitation letter an 8 page print version of the survey, a postcard reminder, and 2 additional waves of the print version were mailed. An overall response rate of $42.24 \%$ was achieved. The high response rate is attributed to the recent (at the time of the survey) public debate of federal climate change legislation, in addition to following the best survey practices possible. It is worth noting that not only might interest in the topic have been heightened somewhat, but that it is possible for this to influence responses if farmers think their answers may influence public discourse or new regulations in the future.

Table 1 presents a summary of the number of responses and percent of sample for the demographic variables surveyed. Eighty-seven percent of respondents answered the question about what year they were born, which was used to calculate respondent age. Over $86 \%$ of respondents were over 45 years of age, and our sample is notably older on average than the general population. A large majority of respondents come from the central, southwest, and northwest regions of the state, which reflects the more heavily populated areas of Indiana. National Agricultural Statistics Service's (NASS) 2010 state statistics and 2007 national census statistics are reported (when available) alongside the respondent demographics for comparison, and indicate good survey coverage when comparing the percentage of respondents from each agricultural statistics district to the percentage of total farms in each district from the 2007 Census of Agriculture. Age of respondents matched up well overall when compared with the 2007 USDA Census of Agriculture data on principal farm operators.

Eighty-nine percent of respondents answered a question about their hours of off-farm employment worked each week, and $>50 \%$ of the respondents said that they do not have any off-farm employment; this is a higher percentage than in the NASS sample. Farms are larger overall in this sample than in the NASS sample, which is likely correlated with less offfarm employment. Since the original random sample was purposefully drawn from a population of corn and soybean farmers who received corn and soybean commodity payments in 2009, this likely excludes smaller farms. The NASS statistics reveal that farms 
Table 1. Number of responses and percentage of sample for various survey demographics compared to state and nation. NASS: National Agricultural Statistics Service

\begin{tabular}{|c|c|c|c|c|}
\hline Characteristic & $\mathrm{n}$ & $\begin{array}{l}\text { Sample } \\
(\%)\end{array}$ & $\begin{array}{c}\text { NASS } \\
\text { Indiana (\%) }\end{array}$ & $\begin{array}{l}\text { NASS } \\
\text { US (\%) }\end{array}$ \\
\hline \multicolumn{5}{|l|}{ Age (yr) } \\
\hline 18-25 (NASS: under 25) & 7 & 0.99 & 0.7 & 0.5 \\
\hline 26-35 (NASS: 25-34) & 25 & 3.52 & 6.8 & 4.8 \\
\hline 36-45 (NASS: $35-44)$ & 64 & 9.01 & 15.1 & 12.1 \\
\hline 46-55 (NASS: 45-54) & 174 & 24.51 & 27.6 & 25.6 \\
\hline 56-65 (NASS: 55-64) & 202 & 28.45 & 24.6 & 27 \\
\hline 66-75 (NASS: 65 and older) & 155 & 21.83 & 25.2 & 29.7 \\
\hline 76 and older & 83 & 11.69 & & \\
\hline \multicolumn{5}{|c|}{ Region (Indiana crop reporting district) } \\
\hline Northern tier: Northwest & 93 & 13.09 & 13.84 & \\
\hline North Central & 82 & 11.54 & 12.31 & \\
\hline Northeast & 93 & 13.09 & 10.92 & \\
\hline Central tier: West Central & 67 & 9.43 & 11.72 & \\
\hline Central & 122 & 17.18 & 20.17 & \\
\hline East Central & 58 & 8.17 & 8.86 & \\
\hline Southern tier: Southwest & 97 & 13.66 & 13.5 & \\
\hline South Central & 55 & 7.74 & 4.42 & \\
\hline Southeast & 43 & 6.05 & 4.27 & \\
\hline \multicolumn{5}{|l|}{ Off-farm Employment } \\
\hline $1-19 \mathrm{~h} \mathrm{wk}^{-1}$ & 78 & 10.74 & & \\
\hline $20-39 \mathrm{~h} \mathrm{wk}^{-1}$ & 55 & 7.57 & & \\
\hline 40 or more h wk ${ }^{-1}$ & 197 & 27.14 & & \\
\hline No off-farm employment & 396 & 54.54 & 33.2 & 35.2 \\
\hline \multicolumn{5}{|c|}{ (NASS: Zero days worked off operation) } \\
\hline \multicolumn{5}{|l|}{ Education (NASS not available) } \\
\hline Did not complete high school & 27 & 3.67 & & \\
\hline Completed high school & 270 & 36.78 & & \\
\hline Some college, no degree & 132 & 17.98 & & \\
\hline Associate's or vocational degree & 83 & 11.31 & & \\
\hline College bachelor's degree & 133 & 18.12 & & \\
\hline Some college graduate work & 18 & 2.45 & & \\
\hline $\begin{array}{l}\text { Completed graduate degree } \\
\text { (M.S. or Ph.D) }\end{array}$ & 72 & 9.67 & & \\
\hline \multicolumn{5}{|c|}{ Total hectares (acres ) as of July 1, 2010} \\
\hline $1-40(1-99)$ & 177 & 24.96 & 62.7 & 54.4 \\
\hline $41-202(100-499)$ & 270 & 38.08 & 24.7 & 31 \\
\hline $203-404(500-999)$ & 102 & 14.38 & 6.2 & 6.8 \\
\hline $405-809(1,000-1,999)$ & 90 & 12.69 & 4.3 & 4.2 \\
\hline$>810(>2000)$ & 70 & 9.87 & 2.1 & 3.6 \\
\hline
\end{tabular}

Table S1 presents a summary of the number of responses and the percent of the sample for each of the responses pertaining to the number of no-till, conservation till, and conventional till area reported in total by the farmers. Corn and soybean cropgrowing area represented was １89000 ha (467 000 acres), and tilling types were roughly equally divided between no-till, conservation till and conventional till (although soybeans were predominantly grown using notill methods). Further details are in Supplement 1.

\subsection{Data analysis}

Statistical techniques were employed to evaluate the reliability of the climate change belief scale developed for our survey instrument, to analyze the data in order to better understand which questions capture similar variance in the ordinal responses to the overall set of questions, and to investigate whether there is a relationship between farmer demographics and climate change beliefs.

Internal consistency of the climate change scale. The reliability and internal consistency of the group of 8 climate change belief questions, together referred to as a 'scale,' (DeVellis 2003) was measured using Cronbach's Alpha (Cronbach 1951) which is a measure of how well the individual items that constitute the scale correlate with one another or with the summated scale scores for all respondents. Because the first 8 questions (see Table 2) all relate to climate

smaller than 41 ha (100 acres ) may be under-represented, while farms larger than 41 ha may be overrepresented in our random sample. However for the purposes of understanding farmer beliefs about climate change and carbon sequestration incentives, excluding smaller farms was deemed appropriate, as a majority of these are likely to be part-time or 'hobby' farms. In addition, larger farms are probably capable of supplying proportionally larger amounts of carbon sequestration than smaller farms. change beliefs and the last 2 questions are about incentives for soil carbon storage, only the first 8 questions were analyzed together to evaluate internal consistency of the scale.

Polychoric principal components analysis. Principal components analysis (PCA) was used as an exploratory technique to analyze which questions account for the most variance in the responses from farmers. If more than one question in the scale captures the same variation in farmer responses to the 
climate change questions, this is useful information for analysis of the relationship between farmer demographics and climate change beliefs.

The ordinal nature of the Likert-scale data must be taken into account when conducting a PCA (Jolliffe 2002). One approach to PCA of such discrete data is to calculate the polychoric correlation matrix (Olsson 1979) for the ordinal Likert question responses and then to conduct PCA using the polychoric correlations in the underlying data. Polychoric PCA of the 8 climate change scale questions was implemented using the polychoric correlation package for Stata (StataCorp 2009, Kolenikov 2011).

Ordered logit analysis of determinants of farmer beliefs. The individual responses to questions from the climate change scale were regressed on farmer demographic and farm characteristic variables to investigate whether there is a relationship between farmer demographics or farm characteristics and farmer beliefs. The ordered logit model was used because of the ordinal nature of dependent variables, which are responses to Likert-scale questions (Long 1997).

\section{RESULTS}

\subsection{Climate change beliefs and opinions about carbon storage incentives}

Table 2 reports categorical and summary descriptive statistics for responses to climate change belief questions. Over $79 \%$ of respondents believe that climate change is an ongoing natural process, and over $45 \%$ agree that human activity contributes to climate change. Responses to these 2 questions are weakly negatively correlated $(\rho=-0.1638)$. A tabulation of the responses to both of these questions together reveals that $36.8 \%$ of respondents agreed or strongly agreed with both statements; $24.2 \%$ of respondents were neutral about climate change being human-caused, while also agreeing that climate change is a natural process; and $18.5 \%$ disagreed or strongly disagreed that climate change is human-caused while agreeing or strongly agreeing that it is a natural process. Responses indicate neutral to slight disagreement with statements that a general warming trend will help farm operations or not affect how farms are operated.

Table 2. Number (percentages in parentheses) of responses (Likert scale, 1 to 5) and percentage of sample responding for climate change perception questions. Percentages may not sum to 100 due to rounding

\begin{tabular}{|c|c|c|c|c|c|c|c|}
\hline Variable & Full statement from survey & $\begin{array}{l}\text { Strongly } \\
\text { disagree } \\
1\end{array}$ & $\begin{array}{l}\text { Disagree } \\
2\end{array}$ & $\begin{array}{c}\text { Neutral } \\
3\end{array}$ & $\begin{array}{l}\text { Agree } \\
4\end{array}$ & $\begin{array}{l}\text { Strongly } \\
\text { agree } \\
5\end{array}$ & Mean \pm SD \\
\hline Natural & Climate change is an ongoing natural process. & $\begin{array}{c}27 \\
(3.60)\end{array}$ & $\begin{array}{c}42 \\
(5.61)\end{array}$ & $\begin{array}{c}84 \\
(11.21)\end{array}$ & $\begin{array}{c}392 \\
(52.34)\end{array}$ & $\begin{array}{c}204 \\
(27.24)\end{array}$ & $3.93 \pm 0.96$ \\
\hline Anthropogenic & $\begin{array}{l}\text { Human activities are contributing to climate } \\
\text { change. }\end{array}$ & $\begin{array}{c}68 \\
(9.08)\end{array}$ & $\begin{array}{c}104 \\
(13.89)\end{array}$ & $\begin{array}{c}233 \\
(31.11)\end{array}$ & $\begin{array}{c}282 \\
(37.65)\end{array}$ & $\begin{array}{c}62 \\
(8.28)\end{array}$ & $3.22 \pm 1.08$ \\
\hline Not_affect_farm & $\begin{array}{l}\text { A change in the climate will not affect how } \\
\text { I operate my farm. }\end{array}$ & $\begin{array}{c}33 \\
(4.42)\end{array}$ & $\begin{array}{c}236 \\
(31.59)\end{array}$ & $\begin{array}{c}228 \\
(30.52)\end{array}$ & $\begin{array}{c}198 \\
(26.51)\end{array}$ & $\begin{array}{c}52 \\
(6.96)\end{array}$ & $3 \pm 1.02$ \\
\hline Warming_will_help & $\begin{array}{l}\text { If there is a general warming trend of the } \\
\text { planet, it will help my farm operation. }\end{array}$ & $\begin{array}{c}41 \\
(5.49)\end{array}$ & $\begin{array}{c}217 \\
(29.05)\end{array}$ & $\begin{array}{c}385 \\
(51.54)\end{array}$ & $\begin{array}{c}92 \\
(12.32)\end{array}$ & $\begin{array}{c}12 \\
(1.61)\end{array}$ & $2.76 \pm 0.8$ \\
\hline Invented & $\begin{array}{l}\text { Climate change is an issue invented just to } \\
\text { scare people. }\end{array}$ & $\begin{array}{c}62 \\
(8.36)\end{array}$ & $\begin{array}{c}201 \\
(27.09)\end{array}$ & $\begin{array}{c}221 \\
(29.78)\end{array}$ & $\begin{array}{c}155 \\
(20.89)\end{array}$ & $\begin{array}{c}103 \\
(13.88)\end{array}$ & $3.05 \pm 1.17$ \\
\hline Extreme & $\begin{array}{l}\text { Climate change will cause more extreme } \\
\text { weather events (flooding, drought, etc.) }\end{array}$ & $\begin{array}{c}41 \\
(5.53)\end{array}$ & $\begin{array}{c}88 \\
(11.86)\end{array}$ & $\begin{array}{c}275 \\
(37.06)\end{array}$ & $\begin{array}{c}296 \\
(39.89)\end{array}$ & $\begin{array}{c}47 \\
(6.33)\end{array}$ & $3.29 \pm 0.95$ \\
\hline Media & $\begin{array}{l}\text { The media is exaggerating the issue of climate } \\
\text { change. }\end{array}$ & $\begin{array}{c}21 \\
(2.81)\end{array}$ & $\begin{array}{c}65 \\
(8.70)\end{array}$ & $\begin{array}{c}168 \\
(22.49)\end{array}$ & $\begin{array}{c}293 \\
(39.22)\end{array}$ & $\begin{array}{c}200 \\
(26.77)\end{array}$ & $3.78 \pm 1.02$ \\
\hline Policies & $\begin{array}{l}\text { I am more likely to be negatively impacted by } \\
\text { policies designed to address climate change } \\
\text { than by climate change itself. }\end{array}$ & $\begin{array}{c}17 \\
(2.28)\end{array}$ & $\begin{array}{c}32 \\
(4.29)\end{array}$ & $\begin{array}{c}192 \\
(25.74)\end{array}$ & $\begin{array}{c}308 \\
(41.29)\end{array}$ & $\begin{array}{c}197 \\
(26.41)\end{array}$ & $3.85 \pm 0.94$ \\
\hline Mkt & $\begin{array}{l}\text { The best way to create incentives to store more } \\
\text { carbon in farm soil is to create a commodity } \\
\text { market in carbon. }\end{array}$ & $\begin{array}{c}95 \\
(12.70)\end{array}$ & $\begin{array}{c}132 \\
(17.65)\end{array}$ & $\begin{array}{c}341 \\
(45.59)\end{array}$ & $\begin{array}{c}157 \\
(20.99)\end{array}$ & $\begin{array}{c}23 \\
(3.07)\end{array}$ & $2.84 \pm 1$ \\
\hline Govtpymt & $\begin{array}{l}\text { The best way to create incentives to store more } \\
\text { carbon in farm soil is to increase government } \\
\text { conservation payments to farmers. }\end{array}$ & $\begin{array}{c}92 \\
(12.28)\end{array}$ & $\begin{array}{c}138 \\
(18.42)\end{array}$ & $\begin{array}{c}270 \\
(36.05)\end{array}$ & $\begin{array}{c}204 \\
(27.24)\end{array}$ & $\begin{array}{c}45 \\
(6.01)\end{array}$ & $2.96 \pm 1.09$ \\
\hline
\end{tabular}


Over $65 \%$ of respondents believe that the media is exaggerating the issue of climate change. However, in a general population survey, Rabe \& Borick (2010) found $47 \%$ agreement with the statement 'the media is overstating the evidence about global warming.' Over $67 \%$ of our sample also believed that they are more likely to be negatively impacted by policies to address climate change than by climate change itself.

Over $34 \%$ of respondents agree or strongly agree that climate change is invented to scare people, while $46.2 \%$ agreed or strongly agreed that climate change will cause more extreme weather events. These 2 findings may seem at odds with one another, but the data reveals a negative correlation $(\rho=-0.5192)$ in the responses to these 2 questions, with $24 \%$ of respondents both disagreeing that climate change is invented and agreeing that it will cause more extreme events. There is a positive correlation $(\rho=0.5634)$ between responses to the anthropogenic and extreme events questions, with $29.9 \%$ of respondents agreeing or strongly agreeing with both statements.

The last 2 questions reported in Table 2 asked farmers about creating incentives to store more carbon in agricultural soils on a farm, and thus are about respondent preferences for government payment or market-based mechanisms that could incentivize adoption of management practices that reduce GHG emissions from agricultural production.

The authors' a priori hypothesis regarding the carbon storage incentives questions was that farmers would have strong opinions about what would incentivize them to store more carbon in their soils: a carbon market or government conservation payments. Farmers' stated preferences for a particular carbon payment mechanism have not been previously assessed. It will not be possible to measure revealed preferences for such payment mechanisms until well-developed commodity markets for carbon or government conservation programs that support adoption of practices that mitigate climate change are established. The mode response to both questions is a 'neutral' opinion, suggesting that farmers may not have well-formed opinions about this aspect of climate policy. This has important implications for research and outreach discussed below.

\subsection{Climate change scale consistency and polychoric PCA}

Cronbach's Alpha for the entire scale administered in the survey is $\alpha=0.7741$ (see Table S2 and supporting text in Supplement 2, www.int-res.com/articles/ suppl/c056p157_supp.pdf, for details), where a value $>0.7$ indicates internal consistency. The internal consistency of the entire set of questions is found to increase if either the 'natural' or 'warming_will_help' questions are removed from the scale. Together with the fact that these 2 items have item-test correlations below 0.5 (Table S2), this evidence suggests that these 2 statements do not capture any additional variance in responses that is not already being captured by other questions in the scale. This finding can inform future development of scales designed to measure the same or similar underlying latent variables. Public opinion polls with similar questions have been developed and administered nationwide, but never tested on a sample as specific as row crop farmers that may be called on to supply soil carbon sequestration to offset emissions elsewhere in the economy.

Consistent with the calculation of Cronbach's Alpha, observations with missing values for individual climate change scale questions were dropped from the analysis, leaving $\mathrm{n}=724$ observations. Three factors were retained and subjected to an oblique rotation to aid interpretability. This particular rotation method was chosen because there is not an a priori reason to expect the factors not to be correlated. The retained factors cumulatively explain $69.1 \%$ of the variance in responses to the overall scale (Table S3 and supporting text in Supplement 3).

Plotting the loadings in the Factor1-Factor2 space depicted in Fig. 1 facilitates interpretation of the

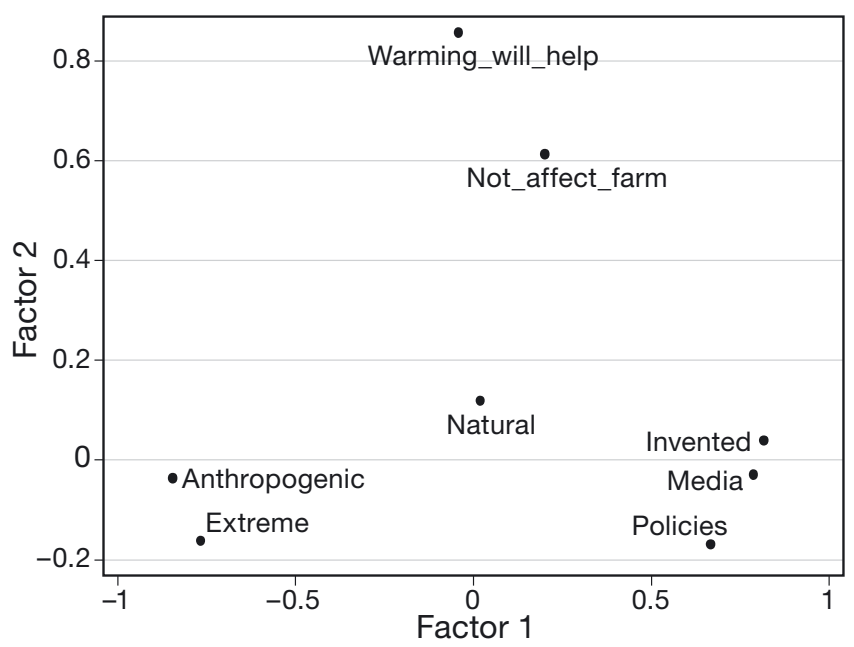

Fig. 1. Oblique oblimin rotation of 3 retained principal component factors depicted graphically in Factor 1-Factor 2 space (for descriptions of variables see Table 2; underlying data contained in Table S4 in Supplement 4, www.int-res. com/articles/suppl/c056p157_supp.pdf) 
rotated factor loadings. Along the horizontal axis, it is clear that the 'anthropogenic' and 'extreme' questions load negatively together on Factor 1. These variables are intuitively closely related to a farmer's understanding of or belief in the science of climate change. The variables 'invented', 'media' and 'policies' all load together positively on Factor 1 and are also closely related, dealing with climate policy and non-scientific public dialog about climate change. The only 2 variables that load on Factor 2 are 'not_affect_farm' and 'warming_will_help', which were most similar in terms of farmer responses detailed in Table 2 . The variable 'natural' is isolated in Fig. 1 because this is the lone variable that loads heavily on Factor 3 (details in Table S4). The PCA indicates that variation in the belief that climate change is a natural ongoing process is not closely related to variation in the other variables. This is consistent with the finding that removing this question from the scale would actually increase scale internal consistency.

\subsection{Relationship between farmer demographics and climate change beliefs}

Variables that load together on a given factor exhibit similar variance with respect to that factor, thus all variables that load in the same direction on a factor are expected to be significantly related to the same farmer demographics. To verify that this is the case, ordered logit regression models were estimated for each variable included in the PCA except 'natural', based on the finding that it loads individually on a single rotated factor and is not consistent with the overall climate change scale of questions (Table S2). The farmer demographics included as explanatory variables were the continuous variables 'farmer age' and 'total farm area', and dummy variables equal to 1 if all farmed area was owned by the respondent, the farm was located in the northern or central tier of Indiana counties, the farmer had no off-farm employment, the respondent did not complete high school or completed a bachelor's degree or higher college degree. Detailed results of these regressions are reported in Tables S5-7 in Supplement 4 at www.int-res.com/articles/suppl/c056p157_ supp.pdf. The variables found to have the most consistent statistically significant relationship with farmer beliefs were farm size, having a bachelors or higher degree, and farmer age. These findings are discussed in greater detail in Supplement 4 and in Section 4.

\section{DISCUSSION}

Agriculture is an important component of the economy, and working agricultural lands supply society with essential grains, livestock and horticultural crops. In addition to these provisioning ecosystem services, agricultural ecosystems act as a manageable sink for atmospheric carbon (USEPA 2012) and have the potential to supply additional climateregulating services to society through cropping systems and livestock management practices. In addition to climate-regulation benefits for society as a whole, some of these practices may have the potential to convey private benefits in terms of cost savings and adaptation that leads to greater resilience in the face of future climate change (Manley et al. 2005). The objective of this research was to understand Indiana farmers' beliefs about climate change, their perceptions of how climate change may or may not impact their farm and whether farmer demographics are statistically associated with climate change beliefs. This greater understanding of farmers' beliefs and perceptions about climate is needed to:

(1) develop accessible and effective outreach and engagement programs to deliver the latest scientific knowledge about how climate change is affected by, and affects, the agricultural community;

(2) inform the development of useable decisionsupport tools for farmers adapting to future climate change; and

(3) evaluate future market-based or government administered programs that seek to harness economic incentives or use regulation to induce changes in agricultural management.

This survey of Indiana farmers found that a large majority $(79 \%)$ believe that climate change is an ongoing natural process, and nearly half $(45 \%)$ believe that human activities are contributing to climate change. This is similar to evidence from North Carolina in which $47.4 \%$ of surveyed producers agreed or strongly agreed with the statement 'I believe human activities are causing changes in the Earth's climate (Rejesus 2012).' Notably, over $30 \%$ of farmers in our sample expressed neither belief nor disbelief that humans are contributing to climate change, suggesting that nearly one-third of respondents either do not know or have not made up their minds about the causes of climate change. Over $50 \%$ of respondents neither agreed nor disagreed with the statement that a general warming trend will help their farm operation. Nearly equal percentages agreed, were neutral about or disagreed that climate change would not affect how they operate their farms. 
Table 3 compares the findings from our survey with larger general population surveys. It is not possible to make a direct comparison between our survey findings and the general population surveys of PRCPP (2010), Stanford (Krosnick \& MacInnis 2011), and Yale (Leiserowitz et al. 2010) since the question structures are not identical. The questions from each survey that are the basis of the comparisons made are reported in the footnotes to Table 3. Farmer responses to questions regarding natural and anthropogenic causes of climate change indicate that only $11.5 \%$ respondents either do not believe that climate change is happening (i.e. is not caused by natural or human factors) or are not sure ('neutral'), suggesting that in comparison to the general population, an equivalent if not higher percentage of Indiana farmers believe that climate change is happening. The percentage of farmer respondents who believe climate change is human-caused is within the range found by general population surveys (34-75\%). A higher overall percentage of farmers believes that climate change is a natural process than the general population (18-34\%), with $18.5 \%$ of respondents agreeing/strongly agreeing that climate change is natural process and simultaneously disagreeing/ strongly disagreeing that it is human-caused. Despite the fact that direct comparison of our farmer survey findings with those from general population surveys is not possible, there do seem to be clear differences in farmers' beliefs about occurrence and causes of climate change compared to the general population. As noted earlier in the paper, very few studies have focused on farmer perceptions of climate change and given the different questions asked, it is difficult to compare our results to other studies. Scottish livestock farmers, however, also reported high levels of uncertainty about the possibility of future change and the impacts of change (Barnes \& Toma 2012).

Related questions about the effects of climate change indicated that $46 \%$ of farmers believe that climate change will cause more extreme weather events, $34.5 \%$ disagree/strongly disagree $(51.5 \%$ neutral) that global warming will help their farm, and $36 \%$ disagree/strongly disagree that climate will not affect how they operate their farm. While these findings appear consistent across questions in the aggregate, they also reveal that over one-third of respondents were neutral about whether climate change would result in more extreme weather events, over half were neutral about whether a warming trend would help their farm and nearly one-third were neutral or agreed/strongly agreed that climate change would not affect how they operate their farms. These findings suggest that a more concrete understanding of the linkages between predicted climate change and cropping conditions and management is needed. This relates to future research, extension of this research to stakeholders and development of decisionsupport tools to help farmers understand and act to adapt to expected climate change.

Table 3. Comparison of key results from Indiana farmer and general population surveys

\begin{tabular}{|c|c|c|c|c|}
\hline $\begin{array}{l}\text { Survey } \\
\text { question } \\
\text { subject }\end{array}$ & $\begin{array}{l}\text { Indiana row crop } \\
\text { farmers (see question } \\
\text { wording in Table 2) }\end{array}$ & $\begin{array}{c}\text { American public opinion } \\
\text { on global warming, Stanford } \\
\text { (Krosnick \& MacInnis 2011) }\end{array}$ & $\begin{array}{l}\text { Opinions about global } \\
\text { warming, PRCPP (2010) }\end{array}$ & $\begin{array}{c}\text { Americans' global warming } \\
\text { beliefs and attitudes, Yale } \\
\text { (Leiserowitz et al. 2010) }\end{array}$ \\
\hline $\begin{array}{l}\text { Climate change is } \\
\text { happening }\end{array}$ & Not asked directly & $75.1 \%{ }^{\mathrm{a}}$ & $59 \%{ }^{b}$ & $61 \% \mathrm{c}$ \\
\hline Anthropogenic & $45 \%^{\mathrm{j}}$ & $75.3 \%{ }^{d}$ & $34 \% \mathrm{e}$ & $50 \%{ }^{\mathrm{f}}$ \\
\hline Natural & $79 \%{ }^{\mathrm{j}}$ & $23.6 \%{ }^{g}$ & $18 \%^{\mathrm{h}}$ & $34 \%{ }^{\mathrm{i}}$ \\
\hline 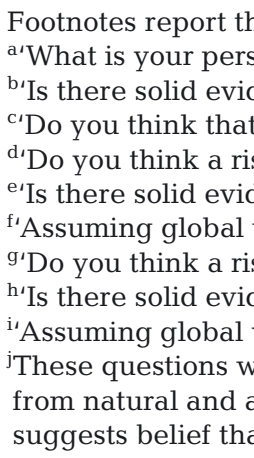 & $\begin{array}{l}\text { ey questions asked by e } \\
\text { oinion on [whether the } \\
\text { he earth is warming?' } \\
\text { warming is happening } \\
\text { e world's temperature is } \\
\text { he earth is warming? ... } \\
\text { hg is happening, do you } \\
\text { e world's temperature is } \\
\text { he earth is warming? ... } \\
\text { gg is happening, do you } \\
\text { t asked in addition to a } \\
\text { ogenic factors, but } 36.8 \\
\text { factors are influencing t }\end{array}$ & $\begin{array}{l}\text { ach general population survey } \\
\text { vorld's temperature has been } g \\
\text { being caused mostly by things } \\
\text { Yes-Because of human activity } \\
\text { think it is ... Caused mostly by } \\
\text { being caused mostly by natur } \\
\text { Yes-Because of natural pattern } \\
\text { think it is ... Caused mostly by } \\
\text { eparate question about wheth } \\
\text { \% of respondents answered bo } \\
\text { he climate }\end{array}$ & $\begin{array}{l}\text { cited. } \\
\text { oing up slowly over the pc } \\
\text { people do?' } \\
\text { human activities?' } \\
\text { al causes?' } \\
\text { natural changes in the en } \\
\text { er respondents believed th } \\
\text { th questions 'agree' and/o }\end{array}$ & $\begin{array}{l}\text { Ivironment? } \\
\text { here was equal influence } \\
\text { 'strongly agree,' which }\end{array}$ \\
\hline
\end{tabular}


Turning to mitigation, the responses to the last 2 questions reported in Table 2 indicate that farmers' opinions about how best to create incentives for carbon storage are not any more or less favorable towards a market-based structure (as might emerge from proposed cap-and-trade markets that include agricultural emissions offsets) or a government conservation payment to create incentives for adoption of farm management practices.

Our regression analysis of the relationship between farmer demographics and climate change beliefs found that farmer age and farm size (total acres) were statistically significantly related to several different beliefs. Farm size was positively related to the belief that climate change was invented to scare people, that the media is exaggerating the issue of climate change and farmers are more likely to be negatively impacted by policies to address climate change than by climate change itself; conversely, farm size is negatively related to the belief that a change in climate will not affect how a farmer operates their farm. Having a bachelor's or higher degree - compared to having a high school diploma - was positively associated with the belief that media is exaggerating the issue of climate change, that climate policies will be more harmful than climate change itself, and that climate change will not affect how the respondent operates their farm. These preliminary findings indicate that additional work needs to be done to know how best to target different kinds of information to different segments of the agricultural community in the classroom and in an outreach setting, and to better understand if there is a systematic reason why the most educated farmers in the sample also seemed most resistant to accepting climate change. Though it is impossible to know for sure, these findings may reflect the highly politicized nature of climate change that seems to supersede public consideration of the issue as a matter of science with the potential to impact livelihoods and not just be a subject of political debate.

Overall, these findings suggest that farmers' beliefs about climate change may be different than previous findings for the general population. Responses to climate change perception questions provide preliminary evidence that Indiana farmers' beliefs are not well-formed, and thus not entrenched, about how a general warming trend will affect their farm, whether climate change will affect how they operate, or whether government or market institutions will create more effective incentives to mitigate GHG emissions from agriculture. The most significant implication of these findings is that there is an oppor- tunity for researchers, government agencies and agricultural extension to help farmers understand the links between climate change and their farm operation, including the kinds of intra- and inter-seasonal management and investment decisions that will be affected by climate change. As noted by Markowitz \& Shariff (2012) the key to increasing support for specific actions or policies to address climate change is to frame the issue in ways that resonate with the target audience such as building on existing moral values and social norms. There is also an opportunity to inform farmers about the advantages and disadvantages of different policy and market mechanisms that may be built into future policy proposals or regulations to implement reductions in GHG emissions. Establishing stronger linkages between research and outreach activities that apply and disseminate knowledge which is useful and usable for end-users is crucial to helping the agricultural community make informed management decisions that will affect or be affected by climate change.

Acknowledgements. Funding for this research was provided by a Mission-Oriented Grant from Purdue University Agricultural Research Programs and the Indiana State Department of Agriculture, and from a seed grant from the Purdue Climate Change Research Center. The authors acknowledge helpful comments and insights that improved the quality of this work that were received from B. Erickson, C. Dobbins, T. Vyn, P. Owens, K. Scanlon, and G. Lynne. The authors are grateful to $\mathrm{C}$. Salazar who managed survey printing, mailing and processing during data collection. This research is reported more fully in J.M.B.'s MS thesis (Becker 2011). The authors are grateful for comments from 3 anonymous reviewers. Any errors or omissions that remain are the authors' alone

\section{LITERATURE CITED}

Barnes A, Toma L (2012) A typology of dairy farmer perceptions towards climate change. Clim Change 112:507-522

Becker JM (2011) An empirical analysis of climate change perceptions and conservation tillage practices of Indiana farmers. MS thesis, Purdue University, West Lafayette, IN

Brklacich M, McNabb D, Bryant C, Dumanski J, Ilbery B, Chiotti Q, Rickard T (1997) Adaptability of agricultural systems to global climate change: a Renfrew County, Ontario, Canada pilot study. In Ilbery B, Chiotti Q, Rickerd T (eds) Agricultural restructuring and sustainability: a geographical perspective. CAB International, Wallingford, p 185-200.

Bryant CR, Smit B, Brklacich M, Johnston TR, Smithers J, Chiotti Q, Singh B (2000) Adaptation in Canadian agriculture to climatic variability and change. Clim Change 45:181-201

Chiotti QP, Johnston T (1995) Extending the boundaries of climate change research: a discussion on agriculture. J Rural Stud 11:335-350 
Cronbach LJ (1951) Coefficient alpha and the internal structure of tests. Psychometrika 16:297-334

- Deressa TT, Hassan RM, Ringer C (2011) Perception of and adaptation to climate change by farmers in the Nile Basin of Ethiopia. J Agric Sci 149:23-31

DeVellis RF (2003) Scale development: theory and applications. Sage Publications, Thousand Oaks, CA

Dillman DA (2009) Internet, mail, and mixed-mode surveys: the tailored design method, 3rd edn. John Wiley, Hoboken, NJ

Easterling WE (1996) Adapting North American agriculture to climate change in review. Agric For Meteorol 80:1-53

$>$ Easterling WE, Crosson PR, Rosenberg NJ, McKenney MS, Katz LA, Lemon KM (1993) Paper 2: Agricultural impacts of and responses to climate change in the Missouri-IowaNebraska-Kansas (MINK) region. Clim Change 24:23-61

Gbetibouo GA (2009) Understanding farmers' perceptions and adaptations to climate change and variability: the case of the Limpopo Basin, South Africa, IFPRI. Discussion Paper. International Food Policy Research Institute, Washington, DC

Gwimbi P (2009) Cotton farmers' vulnerability to climate change in Gokwe District (Zimbabwe): impact and influencing factors. J Disaster Risk Stud 2:81-92

Harrington LMB, Lu M (2002) Beef feedlots in southwestern Kansas: local change, perceptions and the global change context. Glob Environ Change 12:273-282

Holloway L (1999) Understanding climate change and farming: scientific and farmers' constructions of 'global warming' in relation to agriculture. Environ Plan A 31: 2017-2032

Horowitz J, Ebel R, Ueda K (2010) 'No-till' farming is a growing practice. Economic Information Bulletion 70, Economic Research Service, US Department of Agriculture, Washington, DC

Howden SM, Meinke H, Power B, McKeon GM (2003) Risk management of wheat in a non-stationary climate: frost in Central Queensland. In: Post DA. (ed) Integrative modelling of biophysical, social and economic systems for resource management solutions. MSSANZ, Canberra, p 17-22

ISDA (Indiana State Department of Agriculture) (2011) 2009 conservation tillage data - county rankings, data files. Accessed 16 April 2011. www.in.gov/isda/2383.htm

Jolliffe IT (2002) Principal component analysis, 2nd edn. Springer-Verlag, New York, NY

Kolenikov S (2011) Polychoric, polychoric correlation package v1.4. Accessed 4 May 2011. http://web.missouri.edu/ kolenikovs/stata

Krosnick JA, MacInnis B (2011) National survey of American public opinion on global warming. Stanford University with Ipsos and Reuters. Accessed September 29, 2012. http://woods.stanford.edu/sites/default/files/files/GlobalWarming-Survey-Stanford-Reuters-September-2011.pdf

Leiserowitz A, Maibach E, Roser-Renouf C, Smith N (2010) Climate change in the American mind: Americans' global warming beliefs and attitudes in June 2010. Yale Project on Climate Change Communication. Accessed 12 May 2011. http://environment.yale.edu/climate/files/ ClimateBeliefsJune2010.pdf

Long JS (1997) Regression models for categorical and limited dependent variables. Sage, Thousand Oaks, CA

Lorenzoni I, Pidgeon N (2006) Public views on climate change: European and USA perspectives. Clim Change $77: 73-95$
Maddison DJ (2007) The perception of and adaptation to climate change in Africa. World Bank Policy Research Working Paper No. 4308 The World Bank, Development Research Group, Washington, DC.

Malcolm S, Marshall E, Aillery M, Heisey P, Livingston M, Day-Rubenstein K (2012). Agricultural adaptation to a changing climate: economic and environmental implications vary by US Region. ERR-136, US Department of Agriculture, Economic Research Service, Washington, DC

Manley J, van Kooten GC, Moeltner K, Johnson D (2005) Creating carbon offsets in agriculture through no-till cultivation: a meta-analysis of costs and carbon benefits. Clim Change 68:41-65

> Markowitz EM, Shariff A (2012) Climate change and moral judgement. Nat Clim Change 2:243-247

> Mearns LO, Easterling W, Hays C, Marx D (2001) Comparison of agricultural impacts of climate change calculated from high and low resolution climate change scenarios. I. The uncertainty due to spatial scale. Clim Change 51: $131-172$

Milne W (2005) Changing climate, uncertain future: considering rural women in climate change policies and strategies. Canadian Woman Studies 24:49-54

O'Brien K, Pelling M, Patwardhan A, Hallegatte S and others (2012). Toward a sustainable and resilient future. In Field CB, Barros V, Stocker TF, Qin D and others (eds) Managing the risks of extreme events and disasters to advance climate change adaptation. A Special Report of Working Groups I and II of the Intergovernmental Panel on Climate Change. Cambridge University Press, Cambridge, p 437-486.

> Olesen JE, Bindi M (2002) Consequences of climate change for European agricultural productivity, land use and policy. Eur J Agron 16:239-262

Olsson U (1979) Maximum likelihood estimation of the polychoric correlation. Psychometrika 44:443-460

> Osbahr H, Dorward P, Stern R, Cooper S (2011) Supporting agricultural innovation in uganda to respond to climate risk: linking climate change and variability with farmer perceptions. Exp Agric 47:293-316

Paustian K, Babcock BA, Hatfield J, Lal R and others (2004) Agricultural mitigation of greenhouse gases: science and policy options. Report R141, Council on Agricultural Science and Technology, Washington, DC

PRCPP (Pew Research Center for the People and the Press) (2010) Little change in opinions about global warming. Accessed 1 May 2011. http://people-press.org/files/ legacy-pdf/669.pdf

Rabe B, Borick C (2010) The climate of belief: American public opinion on climate change. Issues Gov Stud 31:1-12

Rao KPC, Ndegwa WG, Kizito K, Oyoo A (2011) Climate variability and change: farmer perceptions and understanding of intra-seasonal variability in rainfall and associated risk in semi-arid Kenya. Exp Agric 47:267-291

Rejesus RM (2012.) Farmer perceptions and beliefs about climate change: a North Carolina perspective. NC State Economist, March/April 2012, North Carolina State University, Durham.

> Robinson DA (1999) Agricultural practice, climate change and the soil erosion hazard in parts of southeast England. Appl Geogr 19:13-27

> Rosenzweig C, Iglesius A, Yang XB, Epstein PR, Chivian E (2001) Climate change and extreme weather events implications for food production, plant diseases and 
pests. Glob Chang Hum Health 2:90-104

Smit B, Skinner MW (2002) Adaptation options in agriculture to climate change: a typology. Mitig Adapt Strategies Glob Change 7:85-114

Smith P, Martino D, Cai Z, Gwary D and others (2007) Agriculture. In: Climate Change 2007: Mitigation. Contribution of Working Group III to the Fourth Assessment Report of the Intergovernmental Panel on Climate Change. Cambridge University Press, Cambridge.

StataCorp (2009) Statistics/data analysis, software v11.1. College Station, TX

United States Department of Agriculture, National Agricultural Statistics Service (USDA-NASS) (2007) 2007 Census of Agriculture, State Data. Accessed 16 April 2011. www. agcensus.usda.gov/Publications/2007/Full_Report/index

United States Department of Agriculture, National Agricultural Statistics Service (USDA-NASS) (2010) State and National Corn Production. Accessed 13 May 2011. www.

Editorial responsibility: Gerrit Hoogenboom,

Prosser, Washington, USA
nass.usda.gov/Data_and_Statistics/index

United States Environmental Protection Agency (USEPA) (2012) Greenhouse gas inventory, agriculture. Accessed 4 February 2013. www.epa.gov/climatechange/Downloads/ghgemissions/US-GHG-Inventory-2012-Chapter-6Agriculture.pdf

U2U (Useful to Usable) (2011) Transforming climate variability and change information for cereal crop producers. Accessed 22 February 2012. http://agclimate4u.org

Widcorp (2009) Understanding farmer knowledge and attitudes to climate change, climate variability, and greenhouse gas emissions. December. Report prepared for the Department of Primary Industries, Melbourne

Yeager DS, Larson SB, Krosnick JA, Tompson T (2011) Measuring Americans' issue priorities: a new version of the most important problem question reveals more concern about global warming and the environment. Public Opin Q 75:125-138

Submitted: April 26, 2012; Accepted: November 9, 2012 Proofs received from author(s): March 15, 2013 